\title{
Aktivitas Antimikroba Hasil Fraksinasi Kortex Kayu Jawa (Lannea coromandelica (Houtt.) Merr.)
}

\author{
ISRIANY ISMAIL $^{1}$, ANDI ARMISMAN EDY PATURUSI $^{1}$, ILHAM ARIDANI $^{1}$ \\ ${ }^{1}$ Jurusan Farmasi, Fakultas Kedokteran dan Ilmu Kesehatan, UIN Alauddin Makassar \\ Jl. H.M.Yasin Limpo No. 36 Samata, Kab. Gowa, Sulawesi Selatan 92113 \\ email: isriany.ismail@uin-alauddin.ac.id
}

\begin{abstract}
Kayu Jawa (Lannea cormendalica (Houtt.) Merr.) is native Indonesia plant, which became a typical plant for the treatment of wounds, dysentery, and other infectious diseases in some regions in Indonesia. An effort to explore of active compounds in medicinal plants in Indonesia, had tested the antimicrobial activity of the fraction Kayu Jawa cortex (Lannea coromandelica (Houtt.) Merr). This study aims to determine the polarity of compounds which can provide the best inhibitory activity against Bacillus subtilis, Escherichia coli, Pseudomonas aeruginosa, Salmonella thypi, Staphylococcus aureus, Staphylococcus epidermidis, Streptococcus mutans, Vibrio sp. and Candida albicans. Extraction of Kayu Jawa cortex done by maceration method with solvent n-hexane and methanol. Antimicrobial activity for total extracts was tested with TLC-Autobiographical and fractions of extract with best antimicrobial activity were tested by agar diffusion method. Fractionation conducted with Vacum-Liquid Chromatography (KCV) method with conditioned eluent from a solvent mixture of ethyl acetate:methanol and n-hexane:ethyl acetate. Determination of the class of active compounds done using a spray reagent.

The results showed that the methanol extract and n-hexane extract inhibited the growth of bacteria Escherichia coli, Pseudomonas aeruginosa and Salmonella thypi. The fraction I of methanol extract at Rf 0.64 and fraction I extract n-hexane at Rf 0.02 showed antibacterial effectiveness for Escherichia coli, Salmonella thypi and showed strong inhibition at concentrations 500-750 ppm against Pseudomonas aeruginosa. The chemical components of the Kayu Jawa cortex (Lannea coromandelica (Houtt.) Merr.), which acts as an antimicrobial included in the class of flavonoids.
\end{abstract}

Keywords: antimicrobial, flavonoids, fraction, kayu jawa cortex, Lannea coromandelica

\section{INTISARI}

Kayu Jawa (Lannea cormendalica (Houtt.) Merr.) adalah tumbuhan asli Indonesia yang menjadi tanaman khas untuk pengobatan luka, disentri, dan penyakit infeksi lainnya pada beberapa wilayah di Indonesia. Sebagai upaya untuk menelusuri komponen senyawa aktif pada tanaman obat Indonesia, telah dilakukan pengujian aktivitas antimikroba hasil fraksinasi kortex Kayu Jawa (Lannea coromandelica (Houtt.) Merr). Penelitian ini bertujuan untuk mengetahui golongan kepolaran senyawa yang dapat memberikan aktivitas penghambatan terbaik terhadap Bacillus subtilis, Escherichia coli, Pseudomonas aeruginosa, Salmonella thypi, Staphylococcus aureus, Staphylococcus epidermis, Streptococcus mutans, Vibrio sp. dan Candida albicans. Ektraksi kortex Kayu Jawa dilakukan dengan metode maserasi menggunakan pelarut berturut-turut n-heksan dan metanol. Aktivitas antimikroba diujikan pada ekstrak total dan hasil fraksinasi ekstrak/fraksi terbaik dengan metode KLT-Autobiografi dan difusi agar. Fraksinasi dilakukan dengan metode Kromatografi Cair Vakum (KCV) dengan eluen yang dikondisikan dari campuran pelarut etil asetat:metanol dan n-heksan:etil asetat. Penentuan golongan senyawa aktif dilakukan dengan menggunakan pereaksi semprot.

Hasil penelitian menunjukkan bahwa ekstrak metanol dan ekstrak n-heksan kortex Kayu Jawa (Lannea coromandelica (Houtt.) Merr.) dapat menghambat pertumbuhan bakteri Escherichia coli, Pseudomonas aeruginosa, dan Salmonella thypi. Fraksi I ekstrak metanol pada nilai Rf 0,64 dan 
gabungan Fraksi I Ekstrak n-Heksan pada Nilai Rf 0,02 memberikan efektivitas antibakteri pada pertumbuhan bakteri Escherichia coli, Salmonella thypi serta daya hambat kuat pada konsentrasi 500-750 bpj terhadap Pseudomonas aeruginosa. Komponen kimia kortex Kayu Jawa (Lannea coromandelica (Houtt.) Merr.) yang berperan sebagai antimikroba termasuk dalam golongan flavanoid.

Kata Kunci: antimikroba, flavonoid, fraksi, kortex kayu jawa, Lannea coromandelica

\section{PENDAHULUAN}

Obat tradisional warisan nenek moyang yang terbuat dari bahan alam telah digunakan secara turun-temurun. Dari sekian banyak tanaman yang digunakan sebagai obat, masih banyak yang harus diteliti dan dibuktikan secara ilmiah baik mengenai komponen aktifnya maupun mekanisme kerjanya. Pembuktian secara ilmiah ini diharapkan dapat menghilangkan keraguan dan meningkatkan kepercayaan masyarakat terhadap khasiat obat tradisional yang sekaligus akan meningkatkan rasionalitas penggunaan obat tradisional.

Studi etnobotani (Irma dkk, 2015) melaporkan sebanyak 53 spesies tumbuhan dan terbagi dalam 35 famili yang dimanfaatkan sebagai obat oleh masyarakat Suku Buton di Kecamatan Binongko Kabupaten Wakatobi Sulawesi Tenggara. Organ tanaman yang digunakan adalah daun, getah, bunga, kulit kayu dan kayu.

Kayu Jawa (Lannea cormendalica (Houtt.) Merr.) adalah tumbuhan dari keluarga Anacardiaceae, merupakan salah satu tanaman yang banyak tumbuh di Indonesia khususnya di Sulawesi. Masyarakat Makassar mengenal tanaman ini dengan nama kayu tammate dan di daerah Kabupaten Bantaeng Sulawesi Selatan disebut Kayu China (to'ba' kayu china = kortex kayu jawa). Tanaman ini sering digunakan masyarakat Sulawesi Selatan untuk mengobati beberapa jenis penyakit, misalnya untuk pengobatan luka bakar. Kulit batang Kayu Jawa oleh masyarakat Suku Buto, Kendari digunakan untuk mengobati muntah darah, kudis, mencret. Kayu Jawa ini juga menjadi tumbuhan obat yang khas digunakan oleh masyarakat suku Moronene di Desa Rau-Rau Sulawesi Tenggara. Kulit batang Lannea digunakan oleh masyarakat untuk pengobatan muntah darah dan perawatan pasca melahirkan (Irma dkk, 2015, Indrawati dan Ompo, 2014). Penggunaan lain tanaman Kayu Jawa adalah sebagai analgesik, anti ulkus, dan aphrodisiac, getahnya sebagai penyembuhan luka, daunnya mengobati pembengkakan akibat keseleo, dan kortex kayu jawa sebagai antiinflamasi, antimitosis dan antioksidan.

\section{METODE}

Pengolahan dan ekstraksi sampel (Fachruddin, 2001). Kortex Kayu Jawa (Lannea coromandelica (Houtt.) Merr.), dirajang lalu dikeringkan untuk selanjutnya diekstraksi. Ekstraksi Kortex Kayu Jawa (Lannea coromandelica (Houtt.) Merr.) dilakukan dengan metode maserasi bertingkat menggunakan berturut-turut pelarut n-heksan dan metanol. Filtrat yang diperoleh dipekatkan dengan rotavapor tekanan rendah pada suhu $65^{\circ} \mathrm{C}$. Diperoleh ekstrak kental metanol dan ekstrak n-Heksan.

Penyiapan mikroba uji (Pelczar et al., 2008; Djide dan Sartini, 2008). Mikroba yang digunakan adalah koleksi Laboratorium Mikrobiologi Farmasi UIN Alauddin Makassar yang telah diremajakan dan disuspensikan dengan $\mathrm{NaCl}$ fisiologis $(\mathrm{NaCl}$ 0,9\%) kemudian diukur kekeruhannya dengan menggunakan spektrofotometer UV-Vis pada panjang gelombang 580nm hingga mencapai transmitan 25\% T (bakteri) 75\% T (fungi).

Penapisan aktivitas antimikroba (Djide dan Sartini, 2008). Uji aktivitas antimikroba dilakukan dengan metode difusi. Medium inokulum sebanyak $10 \mathrm{~mL}$ dibuat dengan menambahkan $20 \mu \mathrm{L}$ suspensi mikroba uji dalam medium NA. Sebanyak $20 \mathrm{~mL}$ ekstrak konsentrasi 10000 bpj dari ekstrak n-heksan (non polar) dan ekstrak metanol (polar) diteteskan ke blank disc. Inkubasi dilakukan selama 1 x 24 jam. 
Fraksinasi ekstrak (Gritter, 1991). Fraksinasi ekstrak dilakukan dengan metode Kromatografi Cair Vakum (KCV), menggunakan fase diam silika gel. Untuk ekstrak metanol menggunakan eluen (etil asetat:metanol) dan untuk ekstrak n-Heksan menggunakan eluen (n-heksan:etil asetat). Cairan pengelusi dibuat dengan gradient kepolaran yang meningkat berdasarkan profil Kromatografi Lapis Tipis (KLT). Fraksifraksi yang diperoleh diuapkan dan profil KLT diamati. Fraksi yang memiliki kromatogram dan warna bercak yang sama digabung menjadi satu dan diuji aktivitas antibakteri dengan metode KLT-Bioautografi.

Skrining antimikroba dan uji daya hambat hasil fraksinasi. Uji daya hambat terhadap hasil fraksinasi ekstrak metanol dan n-heksan Kortex Kayu Jawa (Lannea coromandelica (Houtt.) Merr.) dilakukan dengan metode KLT-Bioautografi dan metode difusi agar. Kromatogram hasil elusi fraksi yang telah dibebaskan dari pelarut dilekatkan selama 45 menit pada permukaan medium Nutrien Agar $10 \mathrm{~mL}$ yang telah diinokulasi
$20 \mu \mathrm{L}$ mikroba uji. Diinkubasi pada suhu $37^{\circ}$ C selama 1 x 24 jam, diamati daerah yang memberikan daerah hambat. Daya hambat senyawa diukur dengan metode difusi agar menggunakan blank disc yang ditetesi dengan fraksi teraktif yang telah diencerkan dalam konsentrasi $1000 \mathrm{bpj}, 750 \mathrm{bpj}$ dan $500 \mathrm{bpj}$. Inkubasi dilakukan pada suhu $37^{\circ} \mathrm{C}$ selama 1 x 24 jam dan diukur daerah hambatnya.

Identifikasi bercak aktif dengan beberapa penampakan bercak (Gritter, 1991). Kromatogram disemprot dengan menggunakan pereaksi semprot penanda alkaloid, steroid, flavonoid, fenol, khumarin, floresensi dan pemadaman.

\section{HASIL}

Hasil ekstraksi kortex Kayu Jawa. Hasil ekstraksi kulit kayu (kortex) Kayu Jawa menghasilkan ekstrak polar (pelarut Metanol) dan ekstrak non polar (pelarut n-heksan) dengan rendamen berturut-turut $3,27 \%$ dan $0.56 \%$.

Penapisan Antimikroba. Proses ini terlihat pada tabel 1 .

Tabel 1. Hasil skrining aktivitas antimikroba ekstrak kortex Kayu Jawa (Lannea coromandelica (Houtt.) Merr.) terhadap mikroba uji

\begin{tabular}{|c|c|c|c|c|c|c|c|c|c|c|}
\hline \multirow{2}{*}{ Ekstrak } & \multirow{2}{*}{$\mathrm{C}(\%)$} & \multicolumn{9}{|c|}{ Mikroba Uji } \\
\hline & & $B s$ & $E c$ & $P a$ & $S a$ & $S m$ & $S t$ & $\mathrm{Se}$ & $\mathrm{Vb}$ & $\mathrm{Ca}$ \\
\hline Metanol & 1 & - & + & + & - & - & + & - & - & - \\
\hline n-Heksan & 1 & - & + & + & - & - & + & - & - & - \\
\hline
\end{tabular}

Pemisahan Senyawa. Pemisahan senyawa ekstrak larut metanol kortex Kayu Jawa (Lannea coromandelica (Houtt.) Merr) dengan metode KLT (Kromatografi Lapis Tipis) menggunakan eluen etil asetat:metanol (1:6). Pemisahan senyawa ekstrak larut nHeksan kortex Kayu Jawa (Lannea coromandelica (Houtt.) Merr.) dengan metode KLT (Kromatografi Lapis Tipis) menggunakan eluen n-heksan:etil asetat $(3: 1)$. Pada kromatogram tampak beberapa bercak pada pengamatan menggunakan sinar UV 254 nm dan $366 \mathrm{~nm}$ (Tabel 2 dan 3).

Tabel 2. Hasil KLT ekstrak metanol kortex Kayu Jawa(Lannea coromandelica (Houtt.) Merr.)

\begin{tabular}{ccccc}
\hline & \multicolumn{4}{c}{ Penampakan bercak } \\
\cline { 2 - 5 } No. & \multicolumn{3}{c}{ UV 254 nm $366 \mathrm{~nm}$} \\
\hline $\mathbf{1}$ & 0,84 & Warna & Rf & Warna \\
$\mathbf{n}$ & 0,82 & Hitam & 0,84 & Merah \\
$\mathbf{3}$ & 0,8 & Hitam & 0,82 & Ungu \\
$\mathbf{4}$ & 0,64 & Hitam & 0,8 & Kuning \\
$\mathbf{5}$ & 0,6 & Hitam & 0,64 & Biru Muda \\
\hline
\end{tabular}




\begin{tabular}{ccccc}
\hline $\mathbf{6}$ & 0,36 & Hitam & 0,36 & Biru Terang \\
$\mathbf{7}$ & 0 & Hitam & 0 & Kuning \\
\hline
\end{tabular}

Tabel 3. Hasil KLT ekstrak n-Heksan kortex Kayu Jawa (Lannea coromandelica (Houtt.) Merr.)

\begin{tabular}{ccccc}
\hline & \multicolumn{4}{c}{ Penampakan bercak } \\
\cline { 2 - 4 } No & UV $254 \mathrm{~nm}$ & UV $366 \mathrm{~nm}$ & \\
\cline { 2 - 5 } $\mathbf{1}$ & Rf & Warna & 0,9 & warna \\
$\mathbf{2}$ & 0,9 & Ungu & 0,78 & Ungu \\
$\mathbf{3}$ & 0,78 & Hitam & 0,7 & Hijau Terang \\
$\mathbf{4}$ & 0,7 & Hitam & 0,64 & Hijau \\
$\mathbf{5}$ & 0,64 & Hitam & 0,56 & Jingga \\
$\mathbf{6}$ & 0,56 & Hitam & 0,4 & Merah \\
$\mathbf{7}$ & 0,4 & Hitam & 0,32 & Biru \\
$\mathbf{8}$ & 0,32 & Hitam & 0,3 & Kuning \\
$\mathbf{9}$ & 0,3 & Hitam & 0,16 & Jingga \\
$\mathbf{1 0}$ & 0,16 & Hitam & 0,04 & Hijau \\
$\mathbf{1 1}$ & 0,04 & Hitam & 0,02 & Kuning \\
\hline
\end{tabular}

Fraksinasi ekstrak. Fraksinasi eksrak metanol dan ekstrak n-heksan kortex Kayu Jawa diperoleh masing-masing 12 hasil fraksi (Tabel 4 dan 5). Elusi hasil fraksinasi ekstrak metanol dan ekstrak n-heksan berturut-turut dengan eluen etil asetat:metanol (6:1) dan eluen n-heksan:etil asetat (3:1) diperoleh 3 fraksi dengan karakter yang sama pada penyinaran dengan UV $254 \mathrm{~nm}$ dan UV 366 nm.

Tabel 4. Hasil KLT fraksi ekstrak metanol kortex Kayu Jawa (Lannea coromandelica (Houtt.) Merr.)

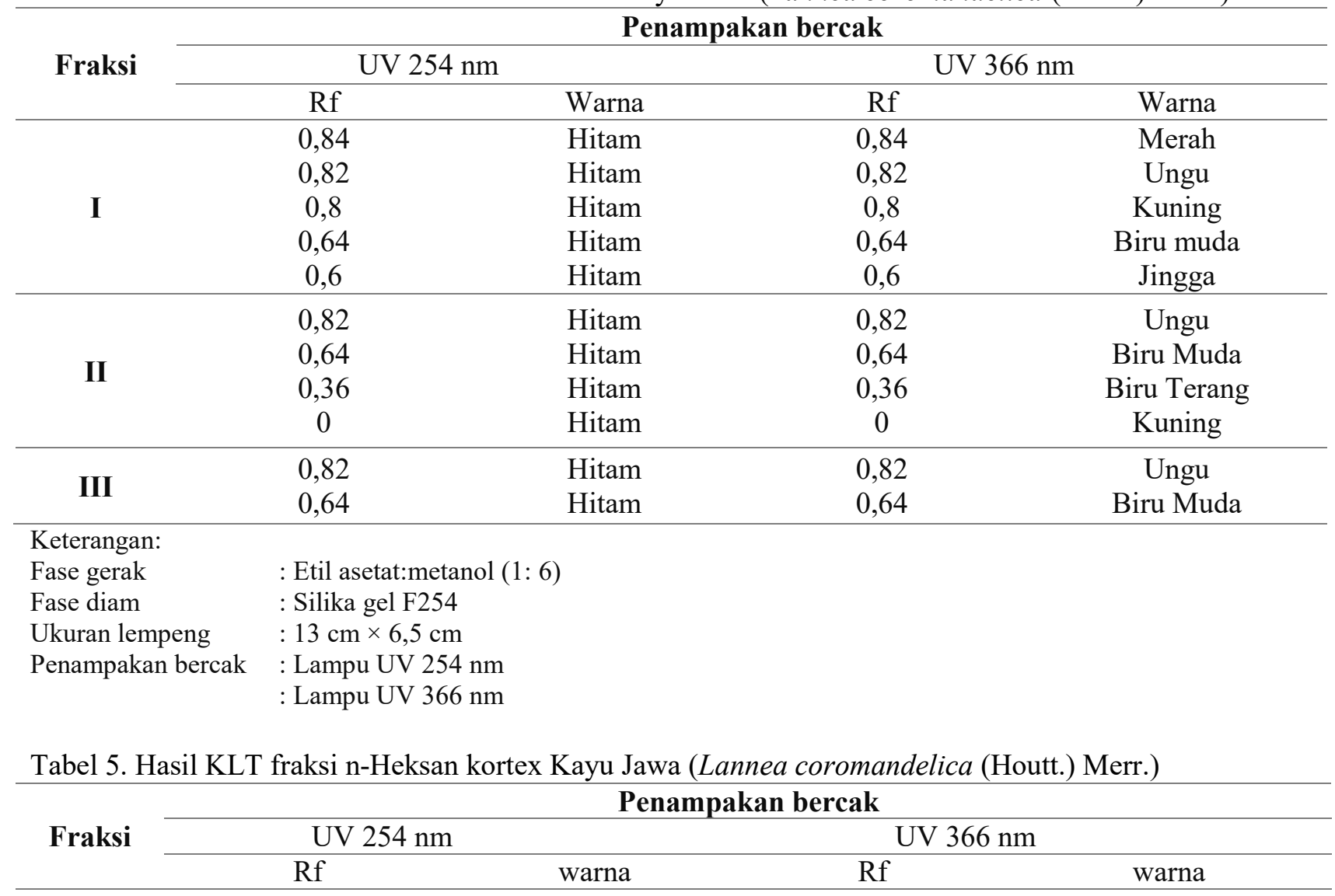




\begin{tabular}{|c|c|c|c|c|}
\hline I & $\begin{array}{c}0,9 \\
0,78 \\
0,38 \\
0,02\end{array}$ & $\begin{array}{l}\text { Ungu } \\
\text { Hitam } \\
\text { Hitam } \\
\text { Hitam }\end{array}$ & $\begin{array}{c}0,9 \\
0,78 \\
0,38 \\
0,02\end{array}$ & $\begin{array}{c}\text { Ungu } \\
\text { Hijau Terang } \\
\text { Hijau } \\
\text { kuning }\end{array}$ \\
\hline II & $\begin{array}{c}0,9 \\
0,7 \\
0,64 \\
0,56 \\
0,4 \\
0,32 \\
0,3 \\
0,16 \\
0,04\end{array}$ & $\begin{array}{l}\text { Ungu } \\
\text { Hitam } \\
\text { Hitam } \\
\text { Hitam } \\
\text { Hitam } \\
\text { Hitam } \\
\text { Hitam } \\
\text { Hitam } \\
\text { Hitam }\end{array}$ & $\begin{array}{c}0,9 \\
0,7 \\
0,64 \\
0,56 \\
0,4 \\
0,32 \\
0,3 \\
0,16 \\
0,04\end{array}$ & $\begin{array}{c}\text { Ungu } \\
\text { Hijau } \\
\text { Jingga } \\
\text { Merah } \\
\text { Biru } \\
\text { Kuning } \\
\text { Jingga } \\
\text { Hijau } \\
\text { Kuning }\end{array}$ \\
\hline III & 0,9 & Ungu & 0,9 & Ungu \\
\hline $\begin{array}{l}\text { Keterangan : } \\
\text { Fase gerak } \\
\text { Fase diam } \\
\text { Ukuran lempeng } \\
\text { Penampakan bercak }\end{array}$ & $\begin{array}{l}: \mathrm{n}-\mathrm{He} \\
: \text { Silik } \\
: 13 \mathrm{cr} \\
: \text { Lam } \\
: \text { Lam }\end{array}$ & & & \\
\hline
\end{tabular}

Hasil penapisan antimikroba. Hasil penapisan aktivitas antimikroba memberi hasil seperti yang ditunjukkan oleh tabel 6 dan 7.

Tabel 6. Hasil uji KLT-Bioautografi fraksi dari ekstrak metanol kortex Kayu Jawa (Lannea coromandelica (Houtt.) Merr.)

\begin{tabular}{ccccc}
\hline \multirow{2}{*}{ Fraksi } & \multirow{2}{*}{} & \multicolumn{3}{c}{ Bakteri uji } \\
\cline { 3 - 5 } & 0,64 & $E c$ & $P a$ & $S t$ \\
\hline $\mathbf{1}$ & 0,36 & + & + & + \\
\hline $\mathbf{2}$ & 0,82 & + & + & + \\
\hline $\mathbf{3}$ & - & & + \\
\hline
\end{tabular}

Tabel 7. Hasil uji KLT-Bioautografi fraksi n-Heksan kortex Kayu Jawa (Lannea coromandelica (Houtt.) Merr.)

\begin{tabular}{ccccc}
\hline \multirow{2}{*}{ Fraksi } & \multirow{R}{*}{} & \multicolumn{3}{c}{ Bakteri uji } \\
\cline { 3 - 5 } & & $E c$ & $P a$ & $S t$ \\
\hline $\mathbf{1}$ & 0,02 & + & + & + \\
\hline $\mathbf{2}$ & 0,04 & + & - & - \\
\hline
\end{tabular}

Keterangan:

$+\quad$ : menghambat pertumbuhan bakteri

- : tidak menghambat pertumbuhan bakteri

Hasil uji daya hambat senyawa aktif antimikroba. Daya hambat fraksi teraktif terhadap mikroorganisme uji dapat dilihat pada tabel 8 .

Tabel 8. Hasil uji daya hambat hasil fraksinasi kortex Kayu Jawa (Lannea coromandelica (Houtt.) Merr.)

\begin{tabular}{|c|c|c|c|c|c|}
\hline \multirow{2}{*}{\multicolumn{2}{|c|}{$\begin{array}{c}\text { Ekstrak/ } \\
\text { Fraksi }\end{array}$}} & \multirow{2}{*}{$\begin{array}{c}\text { C } \\
\text { (bpj) }\end{array}$} & \multicolumn{3}{|c|}{ Bakteri Uji/Daerah hambat (mm) } \\
\hline & & & $E c$ & $P a$ & $S t$ \\
\hline \multirow{4}{*}{ n-Heksan } & \multirow{3}{*}{$\mathrm{I}$} & 1000 & 9 & 10 & 6 \\
\hline & & 750 & 9 & 17 & 11 \\
\hline & & 500 & 6 & 12 & 6 \\
\hline & II & 1000 & 7 & 7 & - \\
\hline
\end{tabular}




\begin{tabular}{|c|c|c|c|c|c|}
\hline & & 750 & 7 & 6 & - \\
\hline & & 500 & 0 & 8 & - \\
\hline \multirow{9}{*}{ Metanol } & \multirow{3}{*}{ I } & 1000 & 0 & 0 & 0 \\
\hline & & 750 & 0 & 0 & 0 \\
\hline & & 500 & 0 & 0 & 0 \\
\hline & \multirow{3}{*}{ II } & 1000 & 0 & - & 0 \\
\hline & & 750 & 0 & - & 0 \\
\hline & & 500 & 0 & - & 0 \\
\hline & \multirow{3}{*}{ III } & 1000 & - & 0 & - \\
\hline & & 750 & - & 0 & - \\
\hline & & 500 & - & 0 & - \\
\hline
\end{tabular}

Keterangan:

- : Pengujian Tidak Dilakukan

Identifikasi senyawa aktif antimikroba. Hasil identifikasi golongan senyawa pada fraksi paling aktif dapat dilihat pada tabel 9.

Tabel 9. Hasil identifikasi komponen senyawa aktif antimikroba hasil fraksinasi ekstrak metanol kortex Kayu Jawa (Lannea coromandelica (Houtt.) Merr.)

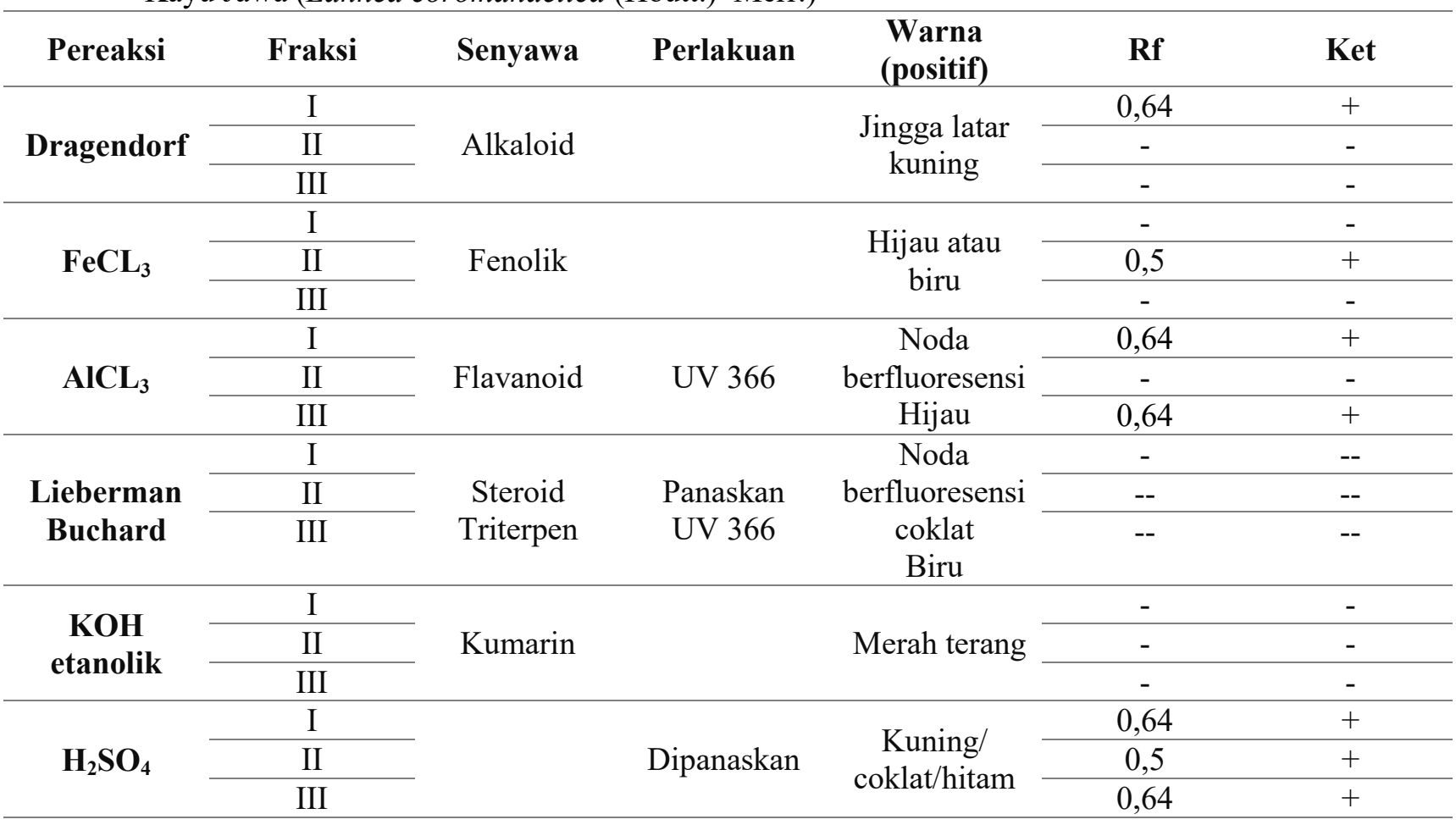

Tabel 10. Hasil identifikasi komponen senyawa aktif antimikroba hasil fraksinasi ekstrak n-Heksan Kortex Kayu Jawa (Lannea coromandelica (Houtt.) Merr.)

\begin{tabular}{|c|c|c|c|c|c|c|}
\hline $\begin{array}{c}\text { Pereaksi } \\
\text { Warna }\end{array}$ & Fraksi & Senyawa & Perlakuan & Warna (positif) & $\mathbf{R f}$ & Ket \\
\hline \multirow{2}{*}{ Dragendorf } & I & \multirow{2}{*}{ Alkaloid } & & \multirow[t]{2}{*}{ Jingga latar kuning } & 0,02 & + \\
\hline & II & & & & 0,04 & + \\
\hline \multirow{2}{*}{$\mathrm{FeCL}_{3}$} & I & \multirow{2}{*}{ Fenolik } & & \multirow[t]{2}{*}{ Hijau atau biru } & - & - \\
\hline & II & & & & - & - \\
\hline \multirow{2}{*}{$\mathrm{AlCL}_{3}$} & I & \multirow{2}{*}{ Flavanoid } & \multirow{2}{*}{ UV 366} & \multirow{2}{*}{ Noda berfluoresensi Hijau } & 0,02 & + \\
\hline & II & & & & 0,04 & + \\
\hline \multirow{2}{*}{$\begin{array}{c}\text { Lieberman } \\
\text { Buchard }\end{array}$} & \multirow{2}{*}{ I } & Steroid & Panaskan & Noda berfluoresensi coklat & - & - \\
\hline & & Triterpen & UV 366 & Biru & - & - \\
\hline
\end{tabular}




\begin{tabular}{|c|c|c|c|c|c|}
\hline & II & & & - & - \\
\hline $\begin{array}{c}\text { KOH } \\
\text { etanolik }\end{array}$ & $\mathrm{I}$ & Kumarin & Merah terang & - & - \\
\hline \multirow{2}{*}{$\mathrm{H}_{2} \mathrm{SO}_{4}$} & $\mathrm{I}$ & \multirow{2}{*}{ Dipanaskan } & Kuning/coklat/hitam & 0,02 & + \\
\hline & II & & & 0,04 & + \\
\hline
\end{tabular}

\section{PEMBAHASAN}

Penggunaan kortex Kayu Jawa (Lannea coromandelica (Houtt.) Merr.) secara empiris dalam mengobati luka dan disentri mungkin saja karena kemampuan antibakteri dari senyawa yang dikandungnya. Penghambatan kontaminasi mikroba pada mukosa mampu mempercepat penyembuhan penyakit tersebut. Meskipun banyak peneliti telah melaporkan aktivitas ekstrak total dalam menghambat pertumbuhan beberapa mikroba patogen, tetapi penelusuran aktivitas senyawa yang lebih murni masih belum dilaporkan.

Pada penelitian ini, proses ekstraksi kortex Kayu Jawa dilakukan dengan metode maserasi bertingkat yang merupakan metode dingin. Metode ini cocok untuk simplisia dengan kandungan senyawa termolabil. Meskipun kandungan senyawa aktif antimikroba pada kortex Kayu Jawa belum diketahui ketahanannya terhadap kenaikan suhu, peneliti berupaya untuk mempertahankan komponen senyawa dari kemungkinan peruraian atau kerusakan.

Metode maserasi bertingkat merupakan suatu proses penyarian simplisia dengan menggunakan lebih dari satu jenis larutan penyari berdasarkan tingkat kepolaran untuk melarutkan senyawa polar kedalam pelarut polar dan senyawa non polar kedalam pelarut non polar secara bergantian. Hal ini dilakukan untuk mengetahui kandungan hasil ekstraksi yang berasal dari suatu bobot simplisia dari pengambilan yang sama. Penyarian diawal dengan penarikan senyawa non polar terlebih dahulu dengan harapan seluruh senyawa non polar termasuk lilin tanaman dapat larut pada penyarian pertama, sehingga pada penyarian berikutnya dengan pelarut polar memungkinkan senyawa yang larut hanya dari golongan senyawa polar. Meskipun simplisia yang digunakan berasal dari organ kayu dari tanaman, tidak menutup kemungkinan simplisia tersebut mengandung senyawa-senyawa lipid. Hasil ekstraksi menunjukkan bahwa kandungan senyawa non-polar memiliki kadar lebih tinggi dibandingkan senyawa yang dapat ditarik oleh pelarut polar. Meskipun kandungan komponen non polar kadarnya lebih tinggi, tampak bahwa kandungan kimia ekstrak non polar tidak menunjukkan keberadaan senyawa steroid dan triterpen (komponen lipid).

Skrining aktivitas antimikroba menunjukkan bahwa ekstrak Metanol dan ekstrak n-Heksan memberikan hasil yang efektif menghambat pertumbuhan bakteri Escherichia coli, Pseudomonas aeruginosa, dan Salmonella thypi. Penghambatan terhadap bakteri Escherichia coli dan Pseudomonas aeruginosa pada senyawa polar dan non polar hasil pengujian ini menunjukkan bahwa penggunaan empiris korteks Kayu Jawa dalam bentuk seduhan dengan air, ataupun penggunaannya sebagai campuran dalam minyak oles mampu mengatasi penyakit diare dan penghambatan bakteri yang dapat memperpanjang proses penyembuhan luka.

Aktivitas penghambatan yang ditunjukkan oleh kedua golongan senyawa ini memungkinkan difraksinasi kembali untuk mendapatkan senyawa yang lebih murni yang mungkin dapat digunakan pada konsentrasi yang lebih kecil dalam penanganan infeksi mikroorganisme. Fraksinasi (pemisahan) senyawa dari ekstrak totalnya dilakukan dengan metode KCV untuk menghasilkan pemisahan senyawa yang lebih sederhana dengan bantuan alat vakum. Pemilihan metode ini dipilih karena prosesnya cepat dan mudah. Kesulitan pada pemisahan ini adalah pada penentuan eluen dan perbandingan eluen yang digunakan.

Uji aktivitas antimikroba hasil fraksinasi pertama yang diperoleh dari masing-masing ekstrak Metanol dan ekstrak n-Heksan dengan 
metode KLT-Bioautografi mampu memberi informasi fraksi teraktif dari 3 fraksi yang dihasilkan. Penghambatan mikroba ditandai dengan adanya daerah bening pada bekasbekas bercak kromatogram. Uji aktivitas antimikroba dengan metode KLTBioautografi ini mampu memberi informasi untuk melakukan fraksinasi lanjutan.

Fraksi aktif yang telah dipisahkan menunjukkan bahwa fraksi I ekstrak n-heksan memiliki daya hambat terbaik pada konsentrasi 500-1000 bpj terhadap bakteri Escherichia coli, Pseudomonas aeruginosa, dan Salmonella thypi. Aktivitas antimikroba lebih lemah pada fraksi II n-heksan dan tidak tampak hambatan pada seluruh fraksi dari ekstrak metanol pada konsentrasi yang sama. Kekuatan daya hambat bakteri menurut David stout (1971) didasarkan atas ukuran diameter zona hambatnya yaitu lemah $(<5 \mathrm{~mm})$, sedang (5-10), kuat (10-20) dan sangat kuat ( $>20$ $\mathrm{mm}$ ) (absor,2006 :7). Sehingga aktivitas penghambatan bakteri Pseudomonas aeruginosa fraksi I ekstrak n-heksan korteks Kayu Jawa pada konsentrasi 750 ppm termasuk kategori aktivitas yang kuat. Kepolaran suatu senyawa sangat mempengaruhi kemampuannya menembus membran sel, termasuk membran sel mikroba. Struktur membran sel yang tersusun atas lipoprotein sangat memungkinkan ditembus oleh senyawa-senyawa bersifat non polar dibanding senyawa polar. Hal ini yang menjadi penghambat penetrasi fraksi dari ekstrak metanol korteks Kayu Jawa ke dalam sel mikroorganisme. Lain halnya jika senyawa masih bercampur antara senyawa polar dan non polar. Struktur senyawa non polar yang berikatan dengan senyawa polar mampu membantu membuka jalur lintas membran dan memungkinkan senyawa polar aktif dapat memberi efek pada sel.

Identifikasi senyawa aktif antibakteri menunjukkan bahwa komponen kimia kortex Kayu Jawa yang berperan sebagai antimikroba termasuk dalam golongan flavonoid. Flavonoid berfungsi sebagai antibakteri dengan cara membentuk senyawa kompleks terhadap protein ekstraseluler yang mengganggu integritas membran sel bakteri.
Flavonoid merupakan senyawa fenol sementara senyawa fenol dapat bersifat koagulator protein.

\section{KESIMPULAN}

1. Ekstrak metanol dan ekstrak n-heksan kortex Kayu Jawa (Lannea coromandelica (Houtt.) Merr.) memberikan aktivitas antimikroba terhadap mikroba uji Escherichia coli, Pseudomonas aeruginosa, dan Salmonella thypi.

2. Fraksi I ekstrak metanol kortex Kayu Jawa (Lannea coromandelica (Houtt.) Merr.) pada nilai Rf 0,64 dan gabungan Fraksi I Ekstrak n-Heksan pada nilai Rf 0,02 memberikan efektivitas antibakteri pada pertumbuhan bakteri Escherichia coli, Pseudomonas aeruginosa, dan Salmonella thypi.

3. Fraksi I ekstrak n-heksan kortex Kayu Jawa (Lannea coromandelica (Houtt.) Merr.) konsentrasi 500 bpj dan 750 bpj berdaya hambat kuat terhadap bakteri Pseudomonas aeruginosa.

4. Komponen kimia Kortex Kayu Jawa (Lannea coromandelica (Houtt.) Merr.) yang berperan sebagai antimikroba termasuk dalam golongan flavanoid.

\section{DAFTAR PUSTAKA}

Djide MN dan Sartini 2008. Dasar-Dasar Mikrobiologi Farmasi. Makassar: Lembaga Penerbit Universitas Hasanuddin.

Djide MN dan Sartini. 2008. Analisis Mikrobiologi Farmasi. Makassar: Lembaga Penerbit Universitas Hasanuddin

Fachruddin H. 2001. Analisis Fitokimia Tumbuhan. Makassar: Fakultas Farmasi, Universitas Hasanuddin.

Gritter RJ, Bobbits JM, Schwarting AE. 1991. Pengantar Kromatografi, Terj. Dr. Kosasih Padmawinata \& Dr. Iwan Sudiro. Bandung: Institut Teknologi Bandung.

Indrawati SY dan Ompo A. 2014. Pengetahuan dan Pemanfaatan Tumbuhan Obat Tradisional Masyarakat Suku 
Moronene di Desa Rau-Rau Sulawesi Tenggara. Biowallacea. vol. 1(1): 39-48. Irma WOI, Ibrahim N, Anam S. 2015. Studi Etnofarmasi Tumbuhan Berkhasiat Obat Pada Suku Buton Di Kecamatan Binongko, Kabupaten Wakatobi,
Sulawesi Tenggara. Galenika Journal of Pharmacy. vol. 2 (1):15-20.

Pelczar, Michael J and Chan ECS. 2008. Dasar-Dasar Mikrobiologi. Terjemahan oleh Hadioetomo, Ratna sari dkk. Jakarta: Universitas Indonesia. 